DOI: 10.46340/ephd.2021.7.3.5

\author{
Olena Hecha \\ ORCID ID: https://orcid.org/0000-0003-2747-0822 \\ Zhytomyr Ivan Franko State University, Ukraine
}

\title{
EMIGRATION OF JEWS OF THE RIGHT BANK OF UKRAINE IN 1923-1930: CAUSES, DIRECTIONS AND SOCIAL PORTRAIT OF MIGRANTS
}

\author{
Олена Геча \\ Житомирський державний університет імені Івана Франка, Україна \\ ЕМІГРАЦІЯ СВРЕЇВ ПРАВОБЕРЕЖНОЇ УКРАЇНИ \\ У 1923-1930 РР.: ПРИЧИНИ, НАПРЯМКИ ТА СОЦАЛЬНИЙ \\ ПОРТРЕТ ПЕРЕСЕЛЕНЦІВ
}

The article deals with Jewish emigration from the territory of Soviet Ukraine, in particular Zhytomyr and Kyiv regions, in the interwar period. Based on a comprehensive analysis of the documents of the Russian-Canadian-American Passenger Agency (RUSCAPA), the State Archives of the Kyiv and Zhytomyr regions, the materials and memories of eyewitnesses of events, the motives and directions of Jewish emigration, and the social affiliation of migrants were revealed. The social, political, and economic situation in Soviet Ukraine, which caused a massive wave of Jewish emigration is characterized. During the entire period of RUSCAPA's existence from 1923 to 1930, about one thousand people left. The People's Commissariat of Foreign Affairs was involved in the registration of passports in the Soviet Union. However, permission to issue them was granted by the People's Commissariat of Internal Affairs (hereinafter - the NKVD) and the People's Commissariat for Military Affairs. The main destinations of Jewish emigration during this period were the United States, Canada, and South America. It was found that the Canadian government was primarily interested in agricultural workers or domestic workers. The Canadian Jewish Society "ICA," as well as the diaspora facilitated emigration to Canada. It was found that leaving the USSR was much more difficult than leaving Western Ukraine. In the late 1920s as a result of the collapse of the root policy in the USSR, the strengthening of authoritarian tendencies caused additional difficulties in producing departure documents. The study also determined what restrictions were created by the order of government bodies to travel outside the Soviet Union. At the same time, the study makes it possible to create a collective and personal portrait of emigrant/emigrants from the USSR.

Keywords: jewish emigration, RUSCAPA, emigrant, Canadian Jewish Society, bureaucracy, Soviet Ukraine.

Доба революцій та воєн, започаткована революцією 1905 р., пов'язується із загостренням антисемітських настроїв та спричиненими ними періодичними погромами. Така ситуація спровокувала хвилю єврейської еміграції, яка не припинилась після Української революції 19171921 рр., як вважають деякі науковці, а тривала, хоча й у значно менших масштабах, до кінця 1920-х рр. Про це свідчать матеріали фонду Російсько-канадсько-американського пасажирського агентства (далі - РУСКАПА) у Державних архівах Київської та Житомирської областей. У фондах містяться: офіційне листування клієнтів 3 пасажирським агентством, анкети та опитувальні листи для емігрантів з теренів Радянського Союзу, телеграми та інші документи, що мають відношення до окреслених областей. РУСКАПА впродовж 1923-1930 pр. забезпечувало еміграцію громадян СРСР до США, Канади, окремих країн Західної Свропи, Південної Америки й Карибського басейну та Південної Африки. За межі СРСР у 1920-х рр., переважно до США і Канади, емігрували євреї, українці, німці, поляки, росіяни. Однак переважна більшість, а це понад $80 \%$ особових справ фонду, стосуються єврейської еміграції з СРСР. 
Актуальність теми визначається необхідністю дослідження неопублікованих і неопрацьованих архівних матеріалів, що можуть допомогти осягнути масштаби, напрямки еміграційного руху євреїв 3 радянської України в міжвоєнний період. Одночасно, дослідження допоможе створити колективний та персональний портрет емігрантів/емігранта. Глобалізаційні процеси пов'язуються 3 новими хвилями еміграції, трудових міграцій, безвідносно до національних ознак. Головним чинником, який спонукає сучасників шукати кращої долі за кордоном, $є$ економічний фактор. Запропоноване дослідження дозволить порівняти фактори, умови, причини, напрямки масової еміграції та соціальну належність емігрантів, що підкреслює його актуальність.

Мета дослідження: на основі всебічного аналізу документів фонду РУСКАПА, матеріалів і спогадів очевидців подій розкрити мотиви, механізми та напрямки еміграції єврейства, з'ясувати соціальну належність переселенців з території радянської України, зокрема Житомирщини та Київщини, протягом 1923-1930 pp.

Серед досліджень, присвячених проблемі єврейської еміграції в окреслений період, варто виділити статтю М. Пархомовського і Д. Харува, в якій автори виділяють дев'ять періодів єврейської еміграції, починаючи з 1648 р. до $2007 \mathrm{p}^{1}$. На їх думку, період між двома світовими війнами найменш вивчений. У цей час з Радянської Росії і Радянського Союзу виїхало понад 300 тисяч євреїв, більшість у 1918-1922 рр. Основна частина євреїв, яка виїхала з Росії в перші роки після революції, оселилася в Західній Європі. Значна частина тих, хто емігрував після революції до Німеччини, переселилася в другій половині 20-х - першій половині 30-х рр. ХХ ст. до Франції, а пізніше - в США. Всього в цей період до США емігрувало близько 100 тисяч радянських євреїв ${ }^{2}$. Другий етап українськоєврейського переселення до Канади, на думку М. Марунчака, розпочався після закінчення Першої світової війни ${ }^{3}$. М. Боровик доводить, що він тривав від 1922 до 1939 р. Автор аргументує ці хронологічні рамки обмеженнями імміграції у перші повоєнні роки ${ }^{4}$.

Масову хвилю еміграції євреїв спричинили соціальна, політична та економічна ситуація в Україні. Перша світова війна, революції, єврейські погроми, занепад штетлів підірвали звичний уклад життя, тісно пов'язаний із релігійними та культурними традиціями, які швидко руйнувалися в окреслених умовах. Євреї опинились у досить скрутному становищі. Заможніші євреї, які не підтримували політики більшовиків, боялись конфіскації приватної власності, націоналізації промисловості, втрати торгових привілеїв. Цей фактор посприяв їх від'їзду за кордон. Однак слід зазначити, що їхали представники різних соціальних категорій, тому економічний фактор був не єдиною причиною, що спонукала до виїзду за кордон: на перший план виходили політичні мотиви, загальна ситуація в СРСР та пам'ять про жахіття погромів, які могли повторитись.

Після закінчення Громадянської війни і створення СРСР виїзд громадян за кордон переходить на бюрократичні рейки. Ці події збіглися із закриттям кордонів перед єврейськими емігрантами в США і Великобританію на хвилі страху перед величезною хвилею біженців, загальним зростанням антисемітизму і поширенням іммігрантами з СРСР «світової революції». США у 1921 р. скоротили квоту євреїв-іммігрантів до 50 тисяч осіб на рік, а потім, в 1924 р. - до 10 тисяч чоловік 5 .

3 УСРР виїхати було значно складніше, ніж із Західної України, практично неможливо. У таємному листі наркома внутрішніх справ В. Манцева від 19 квітня 1922 р. зазначалось: «Тільки Київ, Житомир, Вінниця, Чернігів всім Губотуправам... НКВС роз'яснює, що масові виїзди за кордон у теперішній час $є$ досить небажаними, а тому необхідно при розгляді заяв громадян про видачу закордонних паспортів збирати від судово-каральних чи надзвичайних органів найточніші відомості про особу виїжджаючого, а також необхідне особливе клопотання державних установ чи підприємств

\footnotetext{
${ }^{1}$ Пархомовский, М., Харув, Д. (2009). На четырех краях земли. Еврейская эмиграция из России (1881-1939) Лехаим <https://lechaim.ru/ARHIV/206/kabinet.htm> (2021, серпень, 04).

${ }^{2}$ Генеалогический портал (2021). Эмиграџия из СССР. Еврейские корни.

$<$ https://jroots.info/index.php?option=com_content\&view=article\&id=61\&Itemid=108> (2021, серпень,16).

${ }^{3}$ Марунчак, М. (1991). Історія українців Канади. Вінніпег: накладом Української вільної академії наук в Канаді. 20, 512.

${ }^{4}$ Боровик, М. (1991). Століття українського поселення в Канаді (1891-1991) Монреаль-Оттава: Українська Могилянсько-Мазепинська академія наук (УММАН), 25, 485.

5 Дзира, О.І. (2016). Імміграційна політика Канади щодо суспільно-політичного статусу українських переселенців 1918-1939 pp. disserCat <https://shron1.chtyvo.org.ua/Dzyra_Olesia/Immihratsiina_polityka_Kanady_schodo_ suspilnopolitychnoho_statusu_ukrainskykh_pereselentsiv_1918193.pdf?PHPSESSID=fnrj6mmg1326f4j3vqnlsvfri2>, 35. (2021, серпень, 20).
} 
про дозвіл тим, хто подавав заяву виїзду за кордон. Деякі полегшення у напрямку можливі тільки для емігрантів пролетарського і напівпролетарського походження» ${ }^{1}$.

У Постанові Ради народних комісарів УСРР від липня 1922 р. йшлося про довідки від Обкомгоспу про відсутність комунальних заборгованостей, від фінвідділу про відсутність державних заборгованостей та свідоцтво від ДПУ, що підтверджувало перед народним комісаром іноземних справ чи його уповноваженим (з дозволу яких міг відбутися виїзд за кордон і якими видавалась віза) відсутність перепон до виїзду ${ }^{2}$. Свідоцтва від ДПУ таємно видавалися від імені губотуправ. В «Інструкції № 18 Губотуправам про видачу свідоцтв про відсутність перепон до виїзду за кордон» зазначалося, що «видача свідоцтва й відмова від видачі такого повинні робитись виключно від імені губотуправа» ${ }^{3}$. Про необхідність отримання цієї довідки-дозволу з губернського відділу управління виконавчого комітету для вироблення візи повідомляється в листуванні РУСКАПА у Москві з його відділом у Києві і підтверджується майже в кожній архівній справі.

30 жовтня 1923 р. Радою Народних Комісарів СРСР було ухвалено Статут пасажирського агентства РУСКАПА. Документ закріплював за організацією монополію у справі еміграції з теренів СРСР. Засновниками агентства були Добровільний Флот і Центральне Правління Державного Торгового Флоту, в подальшому - «Русфлот», іноземні структури представляли: Канедіан Пасифік Рельуей Компанії, Голландсько-Американська Лінія і Кунард Стімшип Компані Лімітед ${ }^{4}$.

РУСКАПА надавало допомогу громадянам СРСР в оформленні документів для виїзду за кордон, здійснювало їх відправлення. Матеріали фонду РУСКАПА свідчать, що з території радянської України виїзд був досить обмеженим і складав менше однієї тисячі осіб за весь період існування агентства протягом 1923-1930рр. Підтвердженням цього є особові справи Державного архіву Київської області (1 476 справ), частина яких стосується еміграції єврейських мешканців Бердичівської округи. У Державному архіві Житомирської області зберігаються 581 справа Волинського агентства РУСКАПА емігрантів з Житомирської округи (опис 1) і 22 справи емігрантів 3 Шепетівської округи (опис 2). Фонд Коростенського субагенства Русько-КанадськоАмериканського пасажирського агентства (РУСКАПА) Коростенської округи зберігає 59 справ емігрантів, що намагалися виїхати за межі СРСР протягом 1925-1930 рр. У близько 20-30\% справ зазначається, що поїздка не відбулася. Як свідчать архівні документи, більшість євреїв виїжджали саме із містечок (штетлів), таких як Бердичів, Житомир, Любар, Чуднів, Білогородка, Шепетівка, Коростень, Ізяслав, Умань тощо.

Проаналізувавши особові справи емігрантів Волинського агентства РУСКАПА у Житомирі, яке знаходилося за адресою вулиця Леніна, будинок 6 (сучасна вулиця Київська) 5 , переконуємось у тому, що більшість мешканців Волинської округи бажали виїхати до Канади (301 справа) і США (124 справи). У деяких справах вказуються міста, до яких прямували емігранти: Бостон, Нью-Йорк, Вашингтон, Чикаго, Клівленд. В інших справах є свідчення про еміграцію в країни Південної Америки: до Уругваю - 54 справи, Аргентини - 39 справ, Мексики - 26 справи, навіть були охочі виїхати на Кубу - 7 справ, в Бразилію - 3 справи. Але не всім вдалося емігрувати за різних обставин: відмовлялися самі від поїздки через брак коштів або отримували відмову в агентстві, іноді вказувалося, що поїздка анульована, рідше відмовляли в закордонному паспорті або не змогли виїхати через стан здоров'я. У назвах деяких справ вказувалися релігійна приналежність (баптисти, лютерани) або професія емігранта «цирульник Хая-Тойбе» ${ }^{6}$.

Кожна справа фонду співвідноситься з прізвищем охочого претендента виїхати чи то до Канади, чи до США, чи до країн Південної Америки. Кількісні характеристики пояснюються економічним, соціальним та політичним становищем українських євреїв на цих землях та еміграційною політикою СРСР. Серед документів особових справ збереглися опитувальні листи, медичні довідки, телеграми, ділове листування акціонерного товариства з клієнтами, квитанції про сплату послуг та інші важливі джерела. Вони дають можливість з'ясувати правила виїзду з СРСР та в'їзду до США і Канади, вимоги до громадян, які бажають емігрувати (вік, стан здоров'я, склад родини, рівень грамотності, наявність

\footnotetext{
${ }^{1}$ Державний архів Київської області, $\phi .111$, on.4, спр., арк. 48.

2 Державний архів Київської області, ф. 4205, on.1, сnр. 115, арк. 26.

3 Державний архів Київської області, ф. 4205, оn.1, сnр. 115, арк. 22.

${ }^{4}$ VGD.RU BEБ (2015). Документы об иммигрантах содержащиеся в архивах бывщего СССР

<https://forum.vgd.ru/1582/53708> (2021, серпень, 12).

5 Державний Житомирської області, $\phi .260$.

${ }^{6}$ Державний Житомирської області, ф. 260, on.1, cnp. 495.
} 
запрошення, грошові витрати на поїздку та оформлення закордонних паспортів для дорослих і дітей) та інші, насамперед біографічні, відомості. Якщо в попередній період емігрували в основному бідні єврейські робітники й ремісники, що селилися в Нью-Йорку, Філадельфії, Чикаго, Сент-Луїсі, СанФранциско та інших великих містах США, то значну частину післяреволюційної радянської єврейської еміграції становила інтелігенція і представники середніх і вищих класів. Чимало їх мріяли повернутися на звільнену від більшовиків батьківщину.

В одних із не багатьох родинних спогадів, знаходимо згадки про те, що багато євреїв після революції емігрували з територій колишньої Російської імперії в різних напрямках. Раїса Константиновська (Рабінович) згадувала, як її батьки - інженер Григорій (Герш) Константиновський i його дружина Єлизавета Генріховна (в дівоцтві Піковська) також обговорювали питання еміграції (вночі, коли діти вже повинні були спати). «Я пам’ятаю, ми жили у Шепетівці, на польському кордоні. Багато хто йшов через кордон пішки, перевозячи свій скарб, переводячи худобу... Але мати не хотіла емігрувати до Польщі. Хотіла в США, де вже жили іiі брат (Ісаак з родиною) і сестра (Сва). А це, мабуть, було неможливо. Так ми і залишилися в Союзі... I ніколи про це розмов не було» ${ }^{1}$.

Процес виїзду за межі УСРР керувався «Положенням про в’їзд в межі СРСР і виїзд за межі СРСР», прийнятим ЦВК і Радою Народних Комісарів СРСР 5 червня 1925 р. Оформленням закордонних паспортів у СРСР займався Наркомат іноземних справ. Однак дозвіл на їх видачу надавався Народним комісаріатом внутрішніх справ (далі - НКВС) та Наркоматом з військових справ. Закордонний паспорт діяв протягом 6 місяців з моменту виїзду за межі СРСР і міг бути продовжений ще на 6 місяців за додаткову плату. Порушення строків каралось штрафом².

До імміграції не допускалися: 1) особи з низьким рівнем розумового розвитку, психічно хворі; 2) хворі на туберкульоз або будь-які інфекційні захворювання; 3) німі, сліпі, каліки; 4) злочинці; 5) повії та сутенери; 6) жебраки й волоцюги; 7) особи, які прибувають до Канади за кошти доброчинних інституцій; 8) хронічні алкоголіки; 9) анархісти та члени анархістських організацій; 10) особи, які не вміють читати будь-якою мовою (за винятком дітей до 15 років і дорослих після 55 років) ${ }^{3}$.

Для виїзду з УСРР потрібно було мати: проїзний квиток на корабель (шифскарта), яку переважно оплачували родичі з-за кордону; виклик від них з Канади чи то з іншої країни, закордонний паспорт, довідку з військкомату, медичну довідку, візу. Але, за розпорядженням державних органів, встановлювалися різні додаткові обмеження на в’їзд-виїзд.

Для пред'явлення американському консулу потрібно також було мати: 1) свідоцтво про несудимість; 2) метрику про народження і про шлюб (якщо така була); 3) фотокартки; 4) 10 доларів для оплати американської візи; 5) кишенькові гроші на особисті потреби і для проживання у Москві протягом декількох днів ${ }^{4}$.

Реєстраційні картки видавалися за наявності медичної довідки, опитувального листка і свідоцтва про професію. До відома пасажирів доводилося, що для виїзду в «різні заокеанські країни» урядом встановлювалися різноманітні правила. Вимагалося мати три незавірені фотокартки давати точні відповіді на запитання опитувального листка. У листі потрібно було вказати: 1) на скільки осіб виготовлялася шифскарта та дата заповнення; 2) прізвище, ім'я, по-батькові; 3) дату народження; 4) чи вміли читати і якою мовою; 5) заняття або спеціальність; 6) сімейний стан (одружений чи неодружений, вдівець, розведений тощо); 7) місце народження. У другій частині опитувальника вказували місто і країну, куди їхали і до кого (ступінь спорідненості й точну адресу), а також назву губернського міста, де отримували закордонний паспорт. У кінці зазначалася постійна адреса емігранта 5 .

\footnotetext{
${ }^{1}$ Leonid Volynsky Literary Heritage (2015). Леонид Наумович Вольнский. Жизнь и творчество <https://zwinger.it/zwar/> (2021, серпень, 20).

2 Дзира, O.I. (2016). Імміграційна політика Канади щодо суспільно-політичного статусу українських переселенців 1918-1939 pp. disserCat

<https://shron1.chtyvo.org.ua/Dzyra_Olesia/Immihratsiina_polityka_Kanady_schodo_suspilnopolitychnoho_statusu_ ukrainskykh_pereselentsiv_1918193.pdf?PHPSESSID=fnrj6mmg1326f4j3vqnlsvfri2>, 76 (2021, серпень, 20).

3 Дзира, О.І. (2016). Імміграційна політика Канади щодо суспільно-політичного статусу українських переселенців 1918-1939 pp.disserCat <https://shron1.chtyvo.org.ua/Dzyra_Olesia/Immihratsiina_polityka_Kanady_schodo_ suspilnopolitychnoho_statusu_ukrainskykh_pereselentsiv_1918193.pdf?PHPSESSID=fnrj6mmg1326f4j3vqnlsvfri2>, 55 (2021, серпень, 20).

${ }^{4}$ Державний архів Київської області, ф. 3066, on.1, сnр. 187, арк. 10.

5 Державний архів Київської області, ф. 3066, on.1, сnр. 566, арк. 12.
} 
Окрім зазначених вище документів для вироблення паспорта, існували документи для отримання візи. Це було свідоцтво про професію, про вироблення якого ми дізнаємось 3 листа РУСКАПА до громадянки Махновенцької-Горенштейн Леї з Бердичева від 27 квітня 1926 р., яка виїхала до батька в США як домашня прислуга: «Крім того... просимо негайно прислати свідоцтво про те, що Ви за професією домашня прислуга, назване свідоцтво може бути отримано на Біржі праці, Профспілці чи Міліції» ${ }^{1}$.

Наприклад, з Любара в Аргентину до братів намагалися виїхати Красногар Песла (14 років) i Ріва (12 років). Крім вищеназваних документів, їм обов'язково потрібно було мати дозвіл батьків, а також отримати довідку від Адмінвідділу Бердичева, що перешкод до виїзду немає і оплатити за виготовлення закордонних паспортів ${ }^{2}$. Московське агентство РУСКАПА узгоджувало відправку малолітніх пасажирів 3 кимось із дорослих, хто також направлявся в Аргентину ${ }^{3}$. Коли закордонні паспорти були готові, надсилався лист про терміни прибуття в Київ для відправки на Москву і потім в Аргентину. При собі потрібно було мати реєстраційну картку з відміткою про видачу паспорта, дві незавірених фотокартки кожної сестри, листи від рідних з Аргентини, гроші на особисті потреби, для перебування у Москві і за багаж, а також 3 дол. 10 центів 3 людини на оплату аргентинської візи ${ }^{4}$. У січні 1930 р. на пароплаві «Денерара» вони(брати Красногар) усе ж направилися в Аргентину.

Виїхати за кордон можна було тільки через Москву. Квартира в готелі коштувала чотири карбованця за добу. Витрати в дорозі для особистих потреб - 5 дол., на проживання за кордоном на 56 перших днів потрібно було мати 6 дол. Наприклад, шифскарта 2-го класу від Москви до Нью-Йорка коштувала 202 дол. $^{5}$

Московське товариство РУСКАПА видало спеціальні циркуляри і розпорядження про відправку сімейних і самотніх пасажирів-емігрантів ${ }^{6}$. Окрім цього, згідно з Циркуляром НКВС № 218 від 29 вересня 1922 р. військовозобов'язані були змушені подавати при виїзді свідоцтва від військкоматів про їх відношення до військової повинності й відсутності перешкод з боку військкомату до виїзду ${ }^{7}$. Показовою є справа Кнелера Лейзера Іцковича з Махновки Бердичівської округи, що з сім'єю збирався у 1926 р. в Канаду до міста Вінніпег, де вже проживав його брат. Лейзер Іцкович не міг своєчасно подати документи на закордонний паспорт, тому що не мав довідки з військкомату про зняття його з обліку. До того ж сім'я була бідною, грошей не вистачало на два паспорта, хоча Л. Кнелер був столяром і працював на заводі (не вказано на якому) ${ }^{8}$. За час оформлення документів доньці Хані виповнилося один рік 10 місяців (на початку оформлення документів було шість місяців) і їй потрібно було вже купувати шифскарту за половину вартості, що складало 31 долар 25 центів $^{9}$, а в 1927 р. вартість зросла до 83 доларів 75 центів. Дітям до 16 років окремого паспорта не було потрібно, вони вписувалися до паспорта матері. Ще однією перешкодою для виїзду була невідповідність жіночих імен у документах, і тому було прийнято рішення змінити єврейські імена на російські: Хая (дружина) - Клара, Хана - Анна. Підготовку всіх документів оплатили родичі. I тільки за сприяння Єврейського Імміграційного Товариства в Канаді (IКА) Л. Кнелеру був виданий паспорт за пільговим тарифом як «трудовому елементу», і в березні 1927 р. родина терміново виїхала через Козятин на Москву, а потім в Канаду ${ }^{10}$.

Агенти численних мореплавних компаній безконтрольно й безкарно грабували єврейське й малочисельне українське населення. Іноземний відділ уБердичеві затримував виготовлення закордонного паспорта Кацу Борису (Берко) з містечка Погребище Бердичівської округи, що працював рахівником. Тільки після того, як він заплатив шість карбованців, щоб прискорити цей процес, він отримав паспорт ${ }^{11}$.

\footnotetext{
${ }^{1}$ Державний архів Київської області, ф. 3066, оn.1, сnр. 775, арк. 5.

2 Державний архів Київської області, ф. 3066, on.1, cnp. 566, арк. 19.

3 Державний архів Київської області, ф. 3066, on.1, сnр. 566, арк. 18.

${ }^{4}$ Державний архів Київської області, ф. 3066, on.1, сnр. 566, арк. 3.

5 Державний архів Київської області, ф. 3066, on.1, cnp. 439, арк. 12.

${ }^{6}$ Державний архів Київської області, $\phi .3066$, on.1, спр. 1,2.

${ }^{7}$ Державний архів Київської області, ф. 3066, on.1, сnр. 776, арк.13,42.

8 Державний архів Київської області, ф. 3066, on.1, cnp. 551, арк. 32 зв.

9 Державний архів Київської області, ф. 3066, on.1, cnp. 551, арк. 37.

10 Державний архів Київської області, ф. 3066, on.1, сnр. 551, арк. 1.

${ }^{11}$ Державний архів Київської області, ф. 3066, on.1, сnр. 525, арк. 8.
} 
Прикладом грабунку емігрантів агентами РУСКАПА може бути справа Вейцман Леї Іосіфовни, яка намагалася виїхати в США у 1927 р. з Любара Бердичівської округи. Спочатку їй повідомили, що вартість закордонного паспорту становить 55 крб., але згодом з'ясувалося, що це пільговий тариф для робітників. Так як Вейцман Л. І. була літньою жінкою й перебувала на утриманні сина, іiі цікавило чи може вона розраховувати на такий паспорт. Відповідь була негативною. У Бердичівському адмінвідділі їй повідомили, що вартість закордонного паспорту складає 220 крб., а для «нетрудових елементів» - 330 крб. А також вона наївно цікавилася у листі про можливість вивезення грошей $і$ коштовностей за кордон та яка кількість дозволялася. Виготовлення документів затримувалося, поки 3 наступного ï листа у Московське товариство стало відомо, що ï будинок згорів при загадкових обставинах, жінка була у відчаї і наполягала, що бажає виїхати якнайшвидше ${ }^{1}$.

Кельнер Ліза, 24 років, з Любара, отримала свідоцтво про те, що вона за професією кравчиня, а цього для отримання візи було недостатньо ${ }^{2}$. Примітно те, що документи в Любарі Бердичівської округи видавалися грамотно українською мовою, а печатки були двомовні - їдиш/українська. Підготовкою іiї документів займався Іноземний відділ Бердичівського окрадмінвідділу. Спочатку помилково справа була надіслана до Волинського агентства РУСКАПА у Житомир, пізніше була перенаправлена до Київа. Кельнер Ліза подавала в народний суд документи «на право бідності», але їй відмовили. Спочатку вона заплатила за паспорт 40 крб., але тарифи змінилися у 1926 р. і тому, в жовтні ій потрібно було внести доплату за паспорт ще 110 крб., так як, за документами, вона не належала до «трудової категорії» ${ }^{3}$. Віза закінчилася ще 8 липня, потрібно було ії̈ продовжувати $і$ за все додатково платити. Після того як візу було продовжено до лютого 1927 р., дівчина знову готувала документи і їй все ж таки вдалося виїхати до сестри у Канаду.

Документи готувалися досить тривалий час, процедура для молодих людей, зокрема дівчат, була складною. Справа Фейги Дорфман з Бердичева, що мешкала по вулиці Велика Юридика, 22, це доводить. Їй було 18 років і збиралася виїхати до рідних у Канаду. Початок листування з Київським агентством датується вереснем 1926 р., і тільки у березні 1927 р. вона отримала дозвіл на виїзд до Москви. Досліджуючи особові справи фонду, можна зробити висновок, що цій дівчині вдалося досить швидко пройти всі процедури. Вона навіть змогла отримати паспорт за пільговим тарифом для робітників, що складало 55 крб. Цьому посприяло Канадське Єврейське Товариство «ІКА». Товариство надіслало 50 доларів для виготовлення документів, що засвідчують близько десяти аркушів даної справи ${ }^{4}$. А двадцятирічна Рухель Гітман також з Бердичева, яка була освіченою (в реєстраційній картці вказувалося, що вміла читати будь-якою мовою) і мала довідку, що була домашньою прислугою, не змогла виїхати в Канаду через брак коштів 5 .

Циркуляром № 115 «Б» від 14 грудня 1927 р. були змінені правила для виїзду самотніх жінок за кордон. Канєвська Франя 1903 року народження збиралася на Кубу, але довго з'ясовували, до кого саме вона направляється. Франя була неосвічена, займалася хліборобством, тому агент Л. Жадановський вирішував питання ії виїзду з січня по листопад 1928 р. Коли з'ясувалося, що вона хоче виїхати до нареченого, громадянина США Самарського (ім'я не відоме), не дозволили. Тільки після телеграми Нью-Йоркської Контори Пароплавної Лінії «Ройяль Мейль» від 5 квітня 1929 р. про те, що власник їхньої шифскарти Самарський прибув у Європу, пришвидшили процес підготовки виїзду за кордон і Ф. Канєвської почали вдруге готувати документи. Самарський змушений був прибути у порт Риги для реєстрації шлюбу, оплатити повторно всі документи. I тільки в листопаді 1929 р. вони змогли виїхати до США 6 .

Якщо говорити про виїзд українських євреїв за океан уміжвоєнний період, то Канада за статистичними даними вийшла на перше місце за кількістю переселенців. Це було пов'язано зі встановленням ряду обмежень на в'їзд у США, а також кращими умовами для проживання і праці в Канаді, ніж в Аргентині, Бразилії, Парагваї, Уругваї тощо ${ }^{7}$. Канада відчувала потребу в робочій силі у сфері сільського господарства, а також емігранти мали матеріальну та моральну підтримку діаспори Канади. Саме до Канади в окреслений період емігрувала незначна кількість українців та євреїв.

\footnotetext{
${ }^{1}$ Державний архів Київської області, $\phi .3066$, on.1, сnp. 187, арк. 16 зв.

2 Державний архів Київської області, $\phi .3066$, on.1, сnр. 531, арк. 36.

3 Державний архів Київської області, $\phi .3066$, on.1, сnр. 531, арк. 12.

4 Державний архів Київської області, ф. 3066, on.1, сnр. 390, арк. 18,19,20,21,22,26,30,31.

5 Державний архів Київської області, $\phi .3066$, on.1, сnр. 267, арк. 10.

6 Державний архів Київської області, $\phi .3066$, on.1, сnp. 525, арк.1.

${ }^{7}$ Дністрянський, М. (2008). Етнографія Украӥни. Львів: Видавничий центр ЛНУ імені Івана Франка, 159, 232.
} 
Дослідниця еміграції українців до Канади у міжвоєнний період Олеся Дзира виділяє чотири періоди еміграції до Канади. Зупинимось детельніше на їх характеристиках. Після Першої світової війни протягом 1918-1925 рр. імміграційним законодавством Канади були встановлені обмеження, у зв'язку з економічним становищем.

31923 р. відновилась українсько-єврейська імміграція в Канаду. Цьому процесу також сприяла угода, підписана 15 листопада 1925 р. між канадським урядом і залізничними компаніями «Canadian National Railway» і «Canadian Pacific Railway», що надавала останнім право перевозити емігрантів зі Східної Європи, які мали бути працівниками у сфері сільського господарства чи домашньою прислугою. Для зменшення потоку іммігрантів в часи Великої економічної депресії у 1929 р. було визначено віковий ценз для чоловіків від 18 до 45 р. ${ }^{1}$ А з 1930 р. на в’їзд до Канади мали право тільки реемігранти, жінки, наречені і діти до 18 років попередньо прибулих іммігрантів, які могли їх утримувати і надати житло. Четвертий період 1935-1939 рр. позначився незначним обсягом імміграції у зв'язку із покращенням економічного становища Канади. Слід підкреслити, що мова про Радянську Україну вже не могла йти, це стосувалось лише Західної України, яка в цей період входила до складу Польщі.

Серед інших напрямків переселення була й Палестина. Еміграція в країну тривала легально до 1936 р. Туди переїхало за цей час близько 30 тисяч радянських євреїв ${ }^{2}$. Палестинський еміграційний напрямок суттєво відрізнявся від усіх інших. У ньому головну спонукальну роль відігравали не тільки економічні фактори, але й ідея «повернення до Палестини (історичної батьківщини) і до староєврейської культури» ${ }^{3}$. Окрім того, переселення в Палестину, на певних етапах, було здебільшого еміграцією поодиноких осіб - «халуцім» (піонерів), тоді як єврейська еміграція в інші країни мала переважно родинний характер ${ }^{4}$. Безробіття і важкий клімат у Палестині змусили багатьох повернутися до СРСР.

Наприкінці 20-х pp. XX ст. в СРСР у результаті згортання політики коренізації, посилення авторитарних тенденцій створюються додаткові труднощі у виготовленні (в отриманні) документів на виїзд. Так, наприклад, у липні 1928 р. починає діяти розпорядження НКВС про необхідність довідки з фінансових органів про відсутність заборгованостей перед державою для видачі паспорта. Стали звичними відмови «з політичних мотивів». Зросли консульські збори. До середини 1930-х рр. у СРСР сформувався режим, який практично унеможливлював виїзд радянських громадян. Товариство РУСКАПА у 1930 р. було закрите.

Сталінський закон від 9 червня 1935 р. передбачав смертну кару за «втечу» за кордон5. До середини 1930-х рр. кордони СРСР поступово «закривалися», а заява про бажання емігрувати піддавала небезпеці заявника та його сім'ю, з тієї ж причини переривалися і зв'язки з родичамиемігрантами. Приблизно з цього часу офіційною політикою радянської влади стала теза про те, що жодна радянська людина не хоче залишати СРСР.

Як бачимо, отримання візи на виїзд із більшовицької України було складним і довготривалим процесом. 3 радянських територій українські емігранти виїжджали спершу до Європи, а вже пізніше частина з них перебиралась до Канади та Америки. Перед звичайними громадянами УСРР виникла так звана «залізна завіса», що унеможливлювала переселення за кордон.

Таким чином, незважаючи на відпрацьований механізм бюрократії радянських урядових установ, контроль Державного політичного управління (далі - ДПУ) й перешкодами на митницях, емігрант після «ходіння по митарствах» совєтських канцелярій» і врученні хабаря начальнику

\footnotetext{
${ }^{1}$ Дзира, О.І. (2016). Імміграційна політика Канади щодо суспільно-політичного статусу українських переселенців 1918-1939 pp.disserCat <https://shron1.chtyvo.org.ua/Dzyra_Olesia/Immihratsiina_polityka_Kanady_schodo_ suspilnopolitychnoho_statusu_ukrainskykh_pereselentsiv_1918193.pdf?PHPSESSID=fnrj6mmg1326f4j3vqnlsvfri2 55> (2021, серпень, 20).

${ }^{2}$ Пархомовский, М., Харув, Д. (2009). На четырех краях земли. Еврейская эмиграция из России (1881-1939)

Лехаим $<$ https://lechaim.ru/ARHIV/206/kabinet.htm> (2021, серпень, 04).

${ }^{3}$ Schipper, N. (1930). Historja Żydów oraz przegląd ich kultury. Lwów, II, 91.

${ }^{4}$ Качараба, С. (2011). Еміграчія євреїв із Західної Украӥни в Палестину у 1919-1939 роках <http://prima.Inu.edu.ua/Subdivisions/um/um7/Statti/5-KACHARABA\%20Stepan.htm> (2021, серпень, 20).

${ }^{5}$ Ключ, В. (2012). 9 июня 1935 года в СССР приняли закон о смертной казни за побег за рубеж. Военное Обозрение <http://topwar.ru/15206-9-iyunya-1935-goda-v-sssr-prinyali-zakon-o-smertnoy-kazni-za-pobeg-za-rubezh.html> (2020, грудень, 21).
} 
закордонного відділу таки отримував паспорт. О. Дзира зазначає, що до грудня 1926 р. радянська влада дозволила виїхати 29488 громадян з СРСР ${ }^{1}$.

Ще у 1923 р. НКВС роз'яснювало, що масові виїзди за кордон у той час були досить небажаними. Деякі полегшення можливі були тільки, як зазначалося в урядових документах, для емігрантів пролетарського і напівпролетарського походження. 3 Радянського Союзу вдавалося виїхати лише тим емігрантам, яким посприяло Канадське Єврейське Товариство «ІКА», а також хто мав матеріальну та моральну підтримку діаспори Канади. Уряд Канади надавав переваги працівникам у сфері сільського господарства або ж домашній прислузі. Основними категоріями населення, хто емігрував, були молоді самотні дівчата, які виїжджали до батька, який раніше емігрував, чи до нареченого, молоді сім’ї, рідше молоді чоловіки, які мали професії столяра, кравця, перукаря, рахівника тощо. Поступово перед звичайними громадянами УСРР з'явилася так звана «залізна завіса», що взагалі унеможливлювала переселення за кордон.

Головним джерелом запропонованої розвідки стали матеріали фондів Р-3066 Київського відділення РУСКАПА у Державному архіві Київської області та Р-260 Волинського відділення і Р-262 Коростенського відділення РУСКАПА у Державному архіві Житомирської області. Ці матеріали уперше вводяться до наукового обігу.

Дана робота не вичерпує всіх аспектів порушеної тематики і потребує подальшого глибокого дослідження.

\section{References:}

1. Borovyk, M. (1991). Stolittia ukrainskoho poselennia v Kanadi (1891-1991) [Centuries of Ukrainian settlement in Canada (1891-1991)] Monreal-Ottava: UMMAN, 25. [in Ukrainian].

2. Derzhavnyi Zhytomyrskoi oblasti [State Archives of Kyiv Region], f. 260. [in Russian].

3. Derzhavnyi Zhytomyrskoi oblasti [State Archives of Zhytomyr Region], f. 260, op. 1 spr. 495. [in Russian].

4. Derzhavnyi arkhiv Kyivskoi oblasti [State Archives of Kyiv Region], f. 111, op. 4, spr. 1, ark. 48. [in Russian].

5. Derzhavnyi arkhiv Kyivskoi oblasti [State Archives of Kyiv Region], f. 3066, op.1, spr. 187, ark. 10. [in Russian].

6. Derzhavnyi arkhiv Kyivskoi oblasti [State Archives of Kyiv Region], f. 3066, op.1, spr. 566, ark. 12. [in Russian].

7. Derzhavnyi arkhiv Kyivskoi oblasti [State Archives of Kyiv Region], f. 3066, op.1, spr. 775, ark. 5. [in Russian].

8. Derzhavnyi arkhiv Kyivskoi oblasti [State Archives of Kyiv Region], f. 3066, op.l, spr. 566, ark. 19. [in Russian].

9. Derzhavnyi arkhiv Kyivskoi oblasti [State Archives of Kyiv Region], f. 3066, op.1, spr. 566, ark. 18. [in Russian]. 10. Derzhavnyi arkhiv Kyivskoi oblasti [State Archives of Kyiv Region], f. 3066, op.1, spr. 566, ark. 3. [in Russian].

11. Derzhavnyi arkhiv Kyivskoi oblasti [State Archives of Kyiv Region], f. 3066, op.1, spr. 439, ark. 12. [in Russian].

12. Derzhavnyi arkhiv Kyivskoi oblasti [State Archives of Kyiv Region], f. 3066, op.1, spr. 1,2. [in Russian].

13. Derzhavnyi arkhiv Kyivskoi oblasti [State Archives of Kyiv Region], f. 3066, op.1, spr. 776, ark.13,42. [in Russian].

14. Derzhavnyi arkhiv Kyivskoi oblasti [State Archives of Kyiv Region], f. 3066, op.1, spr. 551, ark. 32 zv. [in Russian].

15. Derzhavnyi arkhiv Kyivskoi oblasti [State Archives of Kyiv Region], f. 3066, op.1, spr. 551, ark. 37. [in Russian].

16. Derzhavnyi arkhiv Kyivskoi oblasti [State Archives of Kyiv Region], f. 3066, op.1, spr. 551, ark. 1. [in Russian].

17. Derzhavnyi arkhiv Kyivskoi oblasti[State Archives of Kyiv Region], f. 3066, op.1, spr. 525, ark. 8. [in Russian].

18. Derzhavnyi arkhiv Kyivskoi oblasti [State Archives of Kyiv Region], f. 3066, op.1, spr. 187, ark. 16 zv. [in Russian].

19. Derzhavnyi arkhiv Kyivskoi oblasti [State Archives of Kyiv Region], f. 3066, op.1, spr. 267, ark. 10. [in Russian].

20. Derzhavnyi arkhiv Kyivskoi oblasti [State Archives of Kyiv Region], f. 3066, op.1, spr. 525, ark..1. [in Russian].

21. Derzhavnyi arkhiv Kyivskoi oblasti [State Archives of Kyiv Region], f. 3066, op.1, spr. 531, ark. 36. [in Russian].

22. Derzhavnyi arkhiv Kyivskoi oblasti [State Archives of Kyiv Region], f. 3066, op.1, spr. 531, ark. 12. [in Russian].

23. Derzhavnyi arkhiv Kyivskoi oblasti [State Archives of Kyiv Region], f. 3066, op.1, spr. 390, ark. 18,19,20,21, 22, 26,30,31. [in Russian].

24. Derzhavnyi arkhiv Kyivskoi oblasti [State Archives of Kyiv Region] ,f. 4205, op.1, spr. 115, ark. 26. [in Russian].

25. Derzhavnyi arkhiv Kyivskoi oblasti [State Archives of Kyiv Region], f.4205, op.1, spr. 115, ark. 22. [in Russian].

26. Dnistrianskyi, M. (2008). Etnohrafiia Ukrainy [Ethnography of Ukraine]. Lviv: Vydavnychyi tsentr LNU imeni Ivana Franka, 159, 232.

27. Dzyra, O.I. (2016). Immihratsiina polityka Kanady shchodo suspilno-politychnoho statusu ukrainskykh pereselentsiv 1918-1939 rr. [Canadian immigration policy on the socio-political status of Ukrainian immigrants

\footnotetext{
${ }^{1}$ Дзира, О.І. (2016). Імміграційна політика Канади щодо суспільно-політичного статусу українських переселенців 1918-1939 pp. disserCat

<https://shron1.chtyvo.org.ua/Dzyra_Olesia/Immihratsiina_polityka_Kanady_schodo_suspilnopolitychnoho_statusu_u krainskykh_pereselentsiv_1918193.pdf?PHPSESSID=fnrj6mmg1326f4j3vqnlsvfri2> (2021, серпень, 20).
} 
in 1918-1939]. disserCat <https://shron1.chtyvo.org.ua/Dzyra_Olesia/Immihratsiina_polityka_Kanady_schodo_ suspilnopolitychnoho_statusu_ukrainskykh_pereselentsiv_1918193.pdf?PHPSESSID=fnrj6mmg1326f4j3vqnlsvfri2> (2021, August, 20). [in Ukrainian].

28. Genealogicheskij portal (2021). Jemigracija iz SSSR. Evrejskie korni [Emigration from the USSR. Jewish roots] $<$ https://jroots.info/index.php?option= com_content \&view=article\&id=61\&Itemid=108 > (2021, August,16). [in Russian].

29. Kacharaba, S. (2011). Emihratsiia yevreiv iz Zakhidnoi Ukrainy v Palestynu u 1919-1939 rokakh. [Emigration of Jews from Western Ukraine to Palestine in 1919-1939].<http://prima.lnu.edu.ua/Subdivisions/um/um7/Statti/ 5-KACHARABA \%20Stepan.htm> (2021, August, 20). [in Ukrainian].

30. Kljuch, V. (2012). 9 ijunja 1935 goda $v$ SSSR prinjali zakon o smertnoj kazni za pobeg za rubezh [On June 9, 1935, the USSR adopted a law on the death penalty for fleeing abroad]. <http://topwar.ru/15206-9-iyunya-1935-godaV-sssr-prinyali-zakon-o-smertnoy-kazni-za-pobeg-za-rubezh.html> (2020, December, 21). [in Russian].

31. Marunchak, M. (1991). Istoriia ukraintsiv Kanady [History of Ukrainians in Canada]. Vinnipeh: nakladom Ukrainskoi vilnoi akademii nauk v Kanadi. 20. [in Ukrainian].

32. Schipper, N. (1930). Historja Żydów oraz przegląd ich kultury [History of Jews and an overview of their culture]. Lviv, II. [in Polish].

33. Parhomovskij, M., Haruv, D. (2009). Na chetyreh krajah zemli. Evrejskaja jemigracija iz Rossii (1881-1939) [On the four ends of the earth. Jewish emigration from Russia]. Lehaim [Leheim] <https://lechaim.ru/ARHIV/206/kabinet.htm> (2021, August, 04). [in Russian].

34. Leonid Volynsky Literary Heritage (2015). Leonyd Naumovych Volynskyi. Zhyzn y tvorchestvo [Leonid Naumovich Volynsky. Life and creation]. <http: zwinger.it/7> (2021, August, 20). [in Russian].

35. VGD.RU WEB (2021) Dokumenty ob immigrantah soderzhashhiesja $v$ arhivah byvshego SSSR [Documents about immigrants contained in the archives of the former USSR] < https://forum.vgd.ru/1582/53708> (2021, August, 12). [in Russian]. 